\title{
Novel 4-Arm Poly(Ethylene Glycol)-Block- Poly(Anhydride-Esters) Amphiphilic Copolymer Micelles Loading Curcumin: Preparation, Characterization, and In Vitro Evaluation
}

\author{
Li Lv, ${ }^{1}$ Yuanyuan Shen, ${ }^{1}$ Min Li, ${ }^{1}$ Xiaofen Xu, ${ }^{1}$ Mingna Li, ${ }^{1}$ \\ Shengrong Guo, ${ }^{1}$ and Shengtang Huang ${ }^{2}$ \\ ${ }^{1}$ School of Pharmacy, Shanghai Jiao Tong University, Shanghai 200240, China \\ ${ }^{2}$ School of Pharmacy, Hubei University of Science and Technology, Xianning 437100, China \\ Correspondence should be addressed to Shengrong Guo; srguo@sjtu.edu.cn and Shengtang Huang; hst6511@163.com
}

Received 8 April 2013; Accepted 2 June 2013

Academic Editor: Ajit S. Narang

Copyright (C) $2013 \mathrm{Li} \mathrm{Lv}$ et al. This is an open access article distributed under the Creative Commons Attribution License, which permits unrestricted use, distribution, and reproduction in any medium, provided the original work is properly cited.

\begin{abstract}
A novel 4-arm poly(ethylene glycol)-block-poly(anhydride-esters) amphiphilic copolymer (4-arm PEG-b-PAE) was synthesized by esterization of 4 -arm poly(ethylene glycol) and poly(anhydride-esters) which was obtained by melt polycondensation of $\alpha$-, $\omega$ acetic anhydride terminated poly(L-lactic acid). The obtained 4-arm PEG-b-PAE was characterized by ${ }^{1} \mathrm{H}-\mathrm{NMR}$ and gel permeation chromatography. The critical micelle concentration of 4 -arm PEG-b-PAE was $2.38 \mu \mathrm{g} / \mathrm{mL}$. The curcumin-loaded 4 -arm PEG-b-PAE micelles were prepared by a solid dispersion method and the drug loading content and encapsulation efficiency of the micelles were $7.0 \%$ and $85.2 \%$, respectively. The curcumin-loaded micelles were spherical with a hydrodynamic diameter of $151.9 \mathrm{~nm}$. Curcumin was encapsulated within 4-arm PEG-b-PAE micelles amorphously and released from the micelles, faster in pH 5.0 than pH 7.4, presenting one biphasic drug release pattern with rapid release at the initial stage and slow release later. The hemolysis rate of the curcumin-loaded 4-arm PEG-b-PAE micelles was 3.18\%, which was below $5 \%$. The $\mathrm{IC}_{50}$ value of the curcumin-loaded micelles against Hela cells was $10.21 \mu \mathrm{g} / \mathrm{mL}$, lower than the one of free curcumin $(25.90 \mu \mathrm{g} / \mathrm{mL})$. The cellular uptake of the curcumin-loaded micelles in Hela cell increased in a time-dependent manner. The curcumin-loaded micelles could induce $\mathrm{G}_{2} / \mathrm{M}$ phase cell cycle arrest and apoptosis of Hela cells.
\end{abstract}

\section{Introduction}

Biodegradable polyanhydrides and polyesters for pharmaceutical applications have received considerable interests in recent decades [1-5]. Polyanhydrides are a particularly promising class of polymers for drug delivery, due to their chemical properties and biocompatibility $[6,7]$. The surfaceeroding properties of polyanhydrides in aqueous medium make them desirable for controlled drug release $[8,9]$. Polyanhydride-based wafers that deliver carmustine for the treatment of brain cancer have been approved by the FDA [10]. Polyesters such as poly(lactic acid), poly(D, L-lactic-coglycolic acid), and poly(E-caprolactone) have been commonly used to form micelles to deliver a variety of drugs [11]. Recently, poly(anhydride-esters) copolymers have been synthesized, in order to combine advantages of polyanhydrides and polyesters [12-14]. These copolymers possess both the degradation and surface erosion properties of individual polyesters and polyanhydrides and may, therefore, provide extended advantages compared to either polyanhydrides or polyesters alone.

Amphiphilic block copolymers have been used extensively in pharmaceutical applications ranging from sustainedrelease technology to gene delivery [15]. In aqueous solution, they can form micelle structures with a hydrophobic inner core and hydrophilic outer shell in aqueous media at or above 
the critical micelle concentration (CMC). The polymeric micelles have unique characteristics, such as nanosize, and good thermodynamic stability in physiological conditions [16]. Upon the CMC, the hydrophobic core regions serve as reservoirs for drugs that have a poor water solubility. Poly(ethylene glycol) (PEG) is often used to build hydrophilic blocks of micelle-forming copolymers, because it is biocompatible, highly soluble, and hydrated in water [16]. Amphiphilic block copolymer composed of PEG and polyanhydride has been prepared by melt copolymerization. By regulating the PEG content, polyanhydrides with adjustable surface erosion rate can be obtained, which are more suitable for a drug-delivery device $[17,18]$. In this study, it was expected that a novel 4-arm poly(ethylene glycol)-b-poly(anhydrideesters) amphiphilic copolymers (4-arm PEG-b-PAE) could be obtained by esterization of 4 -arm poly(ethylene glycol) and poly(anhydride-esters) which was obtained by melt polycondensation of $\alpha$-, $\omega$-acetic anhydride terminated poly(L-lactic acid).

Curcumin, a natural polyphenolic compound isolated from the rhizome of the perennial herb curcuma longa [19-21], has been receiving considerable attention because of its putative cancer prevention and anticancer activities. It was reported that curcumin could interact with many cellular targets such as nuclear factor-kappa B (NF- $\kappa$ B) and transcription factor activator protein-1 (AP-1) [22-24]. Curcumin has antiproliferating effect in some cancer cell lines of human origin [25]. Attractively, clinical trials have proved that curcumin is very safe for humans even at a high dose of $12 \mathrm{~g}$ per day [26, 27]. In this study, curcumin was used as a model drug to evaluate the possibility of the 4-arm PEG-b-PAE as a nanocarrier. The 4-arm PEGb-PAE was characterized by ${ }^{1} \mathrm{H}-\mathrm{NMR}$ and gel permeation chromatography. The curcumin-loaded 4-arm PEG-b-PAE micelles were prepared by a solid dispersion method, and then the characteristics of the cucumin-loaded micelles (e.g., size, $\zeta$-potential, encapsulation efficiency, and drug loading content) were investigated. The in vitro released behavior of curcumin was studied in phosphate buffer solution (PBS, $\mathrm{pH} 7.4$ or $\mathrm{pH} 5.0$ ) and the stability and hemolysis of the micelles were evaluated. In vitro cytotoxicity, cellular uptake, retardation of cell cycle, and induction of apoptosis of micelles to Hela cells were also reported.

\section{Materials and Methods}

2.1. Materials. L-Lactide, diethylene glycol, Sn (II) octoate, succinic anhydride, acetic anhydride, and 4-arm poly(ethylene glycol $)(\mathrm{Mn}=20000)$ were obtained from Aladdin chemistry Co., Ltd. (Shanghai, China). Curcumin was purchased from Alfa-Aesar. Dulbecco's modified eagle's medium was purchased from Invitrogen Corporation (Grand Island, USA). Penicillin-streptomycin, fetal bovine serum (FBS), $0.25 \%(\mathrm{w} / \mathrm{v})$ trypsine, $0.03 \%(\mathrm{w} / \mathrm{v})$ EDTA solution, phosphate buffer solution (PBS), and propidium iodide (PI) were purchased from Solarbio Science \& Technology (Beijing, China). RNase A and Annexin V-FITC/PI were purchased from Beyotime (Suzhou, China).
2.2. Synthesis of Copolymers. 4-arm PEG-b-poly(anhydrideesters) was synthesized by melt polycondensation as shown in Figure 1. Under nitrogen protection, Sn (II) octanoate (100 $\mathrm{mg}$ in $1 \mathrm{~mL}$ of toluene) was added to the mixture of $3.6 \mathrm{~g}$ L-Lactide and $0.87 \mathrm{~mL}$ of diethylene glycol. The reaction mixture was heated to $135^{\circ} \mathrm{C}$ for 25 minutes. The obtained polymer was dissolved in dichloromethane (DCM) and precipitated in ethanol/hexane $(2: 8 \mathrm{v} / \mathrm{v})$ mixture. After drying in vacuum for $48 \mathrm{~h}, 0.8 \mathrm{~g}$ succinic anhydride was added to the polymer and the mixture was heated to $130^{\circ} \mathrm{C}$ for 8 hours. The obtained polymer was dissolved in DCM. $50 \mathrm{~mL}$ of water was introduced and the solution was stirred for 1 hour. The water was separated by a separatory funnel. The polymer was recovered from precipitation in cold diethyl ether and dried under vacuum. After drying the polymer was heated with $60 \mathrm{~mL}$ acetic anhydride to $100^{\circ} \mathrm{C}$ for 8 hours; then the mixture was applied vacuum to remove the excess of acetic anhydride. Once all the unreacted acetic anhydride was removed under vacuum, the temperature was increased to $180^{\circ} \mathrm{C}$ for 6 hours. The poly L-lactic acid based poly(anhydride-esters) was recovered from precipitation of the polymer in cold diethyl ether and dried under vacuum.

4-arm PEG (0.0004 mol) and poly L-lactic acid based poly(anhydride-esters) $(0.0016 \mathrm{~mol})$ were added to the reactor and then were heated to $180^{\circ} \mathrm{C}$, under vacuum for 12 hours. After polycondensation the polymer was dissolved in DMC and precipitated in cold petroleum benzin and dried under vacuum.

\subsection{Characterization of Copolymers}

2.3.1. ${ }^{1} \mathrm{H}$-NMR. ${ }^{1} \mathrm{H}$-NMR spectra were measured on a Varian Mercury plus 400 spectrometer with $\mathrm{CDCl}_{3}$ as solvent. The tetramethylsilane (TMS) was used as an internal standard.

2.3.2. Gel Permeation Chromatography (GPC). GPC measurements were performed at $40^{\circ} \mathrm{C}$ on a Waters HPLC system equipped with a model 1525 binary HPLC pump, a model 2414 refractive index detector and a series of 110 Styragel columns $\left(\mathrm{HR}_{3}\right.$ and $\left.\mathrm{HR}_{4}\right)$. Tetrahydrofuran was used as an eluent at a flow rate of $1.0 \mathrm{~mL} / \mathrm{min}$. The molecular weights were calculated by using a calibration curve which was constructed using polystyrene as standard.

2.3.3. Critical Micelle Concentration (CMC). A steady-state pyrene fluorescence method was used to determine the $\mathrm{CMC}$ of the copolymer according to the method described previously [28]. Briefly, pyrene was dissolved in acetone and added to $5 \mathrm{~mL}$ volumetric flasks to provide a concentration of $6 \times 10^{-7} \mathrm{M}$ in the final solutions. Acetone was then evaporated and replaced with aqueous polymeric micelle solutions with concentrations ranging from 0.1 to $100 \mu \mathrm{g} / \mathrm{mL}$. Fluorescence spectra were recorded on a Hitachi F-7000 spectrophotometer. The scans were performed at medium speed $(240 \mathrm{~nm} / \mathrm{min})$ and at a PMT detector voltage of $350 \mathrm{~V}$. The emission wavelength was carried out at $395 \mathrm{~nm}$ and the excitation spectra were recorded ranging from 300 to $350 \mathrm{~nm}$ with both bandwidths set at $5 \mathrm{~nm}$. A CMC value 


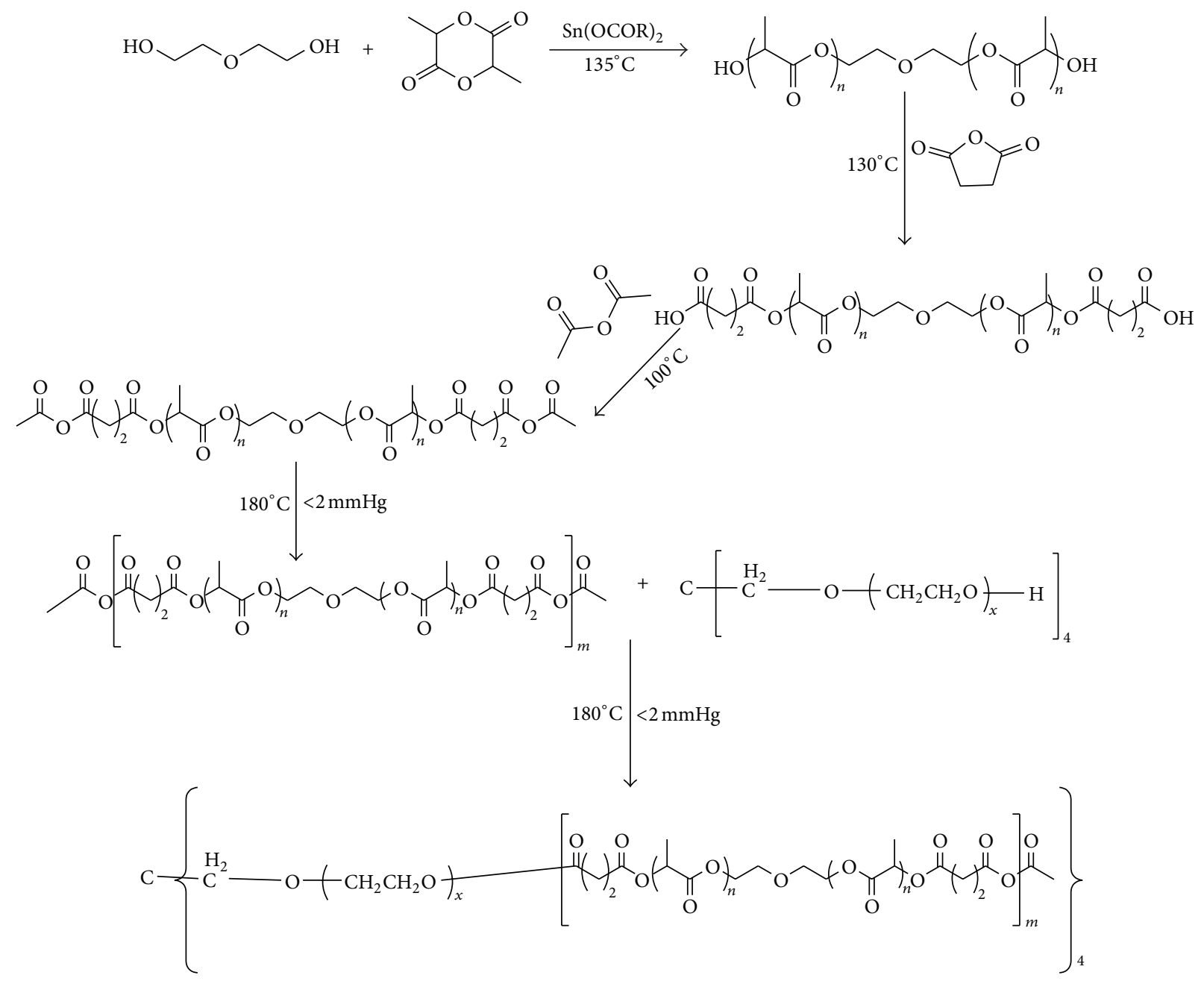

FIGURE 1: Schematic of synthesis of the 4-arm PEG-b-PAE.

was determined from the ratios of pyrene intensities at 337 $\left(I_{337}\right)$ and $335\left(I_{335}\right) \mathrm{nm}$ and calculated from the intersection of two tangent plots of $I_{337} / I_{335}$ versus log concentrations of copolymers.

2.4. Preparation of Micelles. The curcumin-loaded micelles were prepared by a solid dispersion method. Briefly curcumin (5 mg) and 4-arm PEG-b-PAE (50 mg) were dissolved in $10 \mathrm{~mL}$ of dichlormethane by sonication. The organic solvent was evaporated on a rotary evaporator under reduced pressure at $40^{\circ} \mathrm{C}$ to obtain a homogenous coevaporation curcumin/copolymer matrix. The resulting matrix was hydrated by adding $20 \mathrm{~mL}$ of water and then sonicated at $200 \mathrm{w}$ for $5 \mathrm{~min}$; the power was pulsed for $5 \mathrm{~s}$ every $30 \mathrm{~s}$ to minimize increases in temperature. The formed suspension was centrifuged at $4000 \mathrm{rpm}$ for $20 \mathrm{~min}$ to remove the aggregated particles and unencapsulated free curcumin, and then filtered through a $0.45 \mu \mathrm{m}$ filter (Agela Technologies Inc., China), followed by lyophilization for 3 days to get the powdered form of micelles. Empty 4-arm PEG-b-PAE micelles were prepared by the same way.

\subsection{Characterization of Polymeric Micelles}

2.5.1. Particle Size, Size Distribution, and $\zeta$-Potential. The average particle size and polydispersity (PDI) of micelles were determined by dynamic light scattering (DLS) using a Malvern Instrument zeta size nano-s at a detection angle of $173^{\circ}$. $\zeta$-potential was measured using the BC Haven instruments corporation 90 plus particle size analyzer. The samples were dispersed in distilled water at $25^{\circ} \mathrm{C}$ and diluted to a suitable density.

2.5.2. Transmission Electron Microscopy (TEM) Morphology. The morphological characteristics of polymeric micelles were examined by transmission electron microscopy (TEM, Tecnai $G_{2}$ spirit Biotwin). The curcumin-loaded micelles were diluted with distilled water and placed on a copper grid covered with nitrocellulose.

2.5.3. Evaluation of the Drug Encapsulation Efficiency and Drug Loading Content. The amount of encapsulated curcumin in the micelles and the drug loading content were evaluated by direct method. Briefly, $10 \mathrm{~mL}$ of acetonitrile was 
added to $2 \mathrm{mg}$ of the freeze-dried micelles powder in order to disrupt the micelles structure. The solution was dried under nitrogen, then dissolved in mobile phase, centrifuged at a rate of $10000 \mathrm{rpm}$ for 10 minutes, and filtered through $0.45 \mu \mathrm{m}$ filter to obtain a clear solution; then the sample solution was determined at $425 \mathrm{~nm}$ by using a Shimadzu HPLC system, equipped with an LC-10ADvp pump, an SPD-17310 Avp UVvis detector and a Diamonsil $\mathrm{C}_{18}$ reversed phase column 174 $(4.6 \mathrm{~mm} \times 250 \mathrm{~mm}, 5 \mu \mathrm{m})$. The mobile phase was composed of an acetonitrile/3\% acetic acid $(75 / 25, \mathrm{v} / \mathrm{v})$ at a temperature of $30^{\circ} \mathrm{C}$ and a flow rate of $1.0 \mathrm{~mL} / \mathrm{min}$. The encapsulation efficiency and drug loading content were calculated using (1) as follows:

$$
\begin{aligned}
& \text { Encapsulation efficiency }(\%) \\
& \qquad=\frac{\text { weight of curcumin in micelles }}{\text { weight of feeding curcumin }} \times 100 \%,
\end{aligned}
$$

Drug loading content (\%)

$$
=\frac{\text { weight of curcumin in micelles }}{\text { weight of micelles }} \times 100 \% \text {. }
$$

2.5.4. Crystallographic Study. Crystallographic assay was performed on curcumin powders, empty 4-arm-PEG-PAE micelles, and the curcumin-loaded 4-arm PEG-b-PAE micelles free-dried powers by a Rigaku 195 D/max 2200/PC diffractometer using a $\mathrm{Cu}-\mathrm{K} \alpha$ radiation source $(40 \mathrm{kV}$, $20 \mathrm{~mA})$. The samples were scanned over a $2 \theta$ range of $5-45^{\circ}$ at a rate of $5^{\circ} / \mathrm{min}$.

2.6. In Vitro Release Study. In vitro release behavior of curcumin from the 4-arm PEG-b-PAE micelles was developed by dialysis method [29]. Briefly, the curcumin-loaded 4-arm PEG-b-PAE micelles (10 mg) were dispersed in $3 \mathrm{~mL}$ PBS $(0.01 \mathrm{M}, \mathrm{pH} 7.4$ or $\mathrm{pH} 5.0)$ containing $1 \% \mathrm{v} / \mathrm{v}$ of Tween 80 (to maintain a sink condition) and then placed in a dialysis tube (Snakeskin, Pierce, USA) with a molecular weight cut-off of $3500 \mathrm{Da}$. The dialysis tube was suspended in $12 \mathrm{~mL}$ of release medium and placed in a shaking water bath at $37^{\circ} \mathrm{C}$ with a shaking speed of $120 \mathrm{rpm}$. At predetermined time points, the release medium was completely drawn and replaced with fresh incubation medium. The amount of curcumin in the release medium was determined by HPLC.

2.7. Hemolysis by the Curcumin-Loaded Micelles. Briefly fresh blood from Sprague-Dawley rat was collected in heparinized tubes and washed three times with $0.9 \% \mathrm{NaCl}$ by centrifugation at $2800 \mathrm{rpm}$ for $5 \mathrm{~min}$ and suspended in $0.9 \% \mathrm{NaCl}$ solution $(2 \% \mathrm{v} / \mathrm{v})$. Erythrocytes suspension $(0.1 \mathrm{~mL})$ was added to $0.9 \mathrm{~mL}$ of the curcumin-loaded micelles $(100 \mu \mathrm{g} / \mathrm{mL}), 0.9 \%$ $\mathrm{NaCl}$ solusion (negative control group with $0 \%$ hemolysis) and distilled water (positive control group with 100\%), respectively, then incubated for 2 hours in a shaker incubator at $37^{\circ} \mathrm{C}$. After centrifugation at $3000 \mathrm{rpm}$ for $10 \mathrm{~min}$, the absorbance of the supernatant was determined at $540 \mathrm{~nm}$.
The degree of hemolysis was determined by the following equation:

$$
\operatorname{Hem}(\%)=\frac{\mathrm{ABS}-\mathrm{ABS}_{0}}{\mathrm{ABS}_{100}-\mathrm{ABS}_{0}} \times 100,
$$

where $\mathrm{ABS}_{100}$ and $\mathrm{ABS}_{0}$ are the absorbances of the solution at $100 \%$ and $0 \%$ hemolysis, respectively.

2.8. Characteristics of Micelles Uptake. The characteristics of micelles cellular uptake were studied by flow cytometry. Briefly, Hela cells $\left(3.0 \times 10^{5}\right.$ cells in $2 \mathrm{~mL}$ medium $)$ were seeded in 6-well plates and incubated overnight. The medium was removed, and the cells were washed twice with PBS and incubated in serum-free medium for different times with the curcumin-loaded 4-arm PEG-b-PAE micelles (curcumin concentration was $10 \mu \mathrm{g} / \mathrm{mL}$ ) for $24 \mathrm{~h}$ at $37^{\circ} \mathrm{C}$. Cells treated with only medium were used as control. After incubation, the cells were washed three times with ice-cold PBS, and then cells were collected by centrifugation and resuspended in $0.5 \mathrm{~mL}$ PBS. The amount of uptake was analyzed by a flow cytometry (BD LSRFortessa, Becton Dickinson), after excitation with $405 \mathrm{~nm}$ argon lasers and detection with a 515545 band-pass filter.

2.9. In Vitro Cytotoxicity. The in vitro antitumor activity of the curcumin-loaded micelles and free curcumin was determined by MTT assay. Briefly, Hela cells (obtained from Shanghai Institute of Cell Biology, Chinese Academy of Sciences) in their logarithmic growth were seeded in 96well plates at a density of 5000 cells per well in a final volume of $200 \mu \mathrm{L}$ medium and allowed to adhere overnight. The culture medium was carefully replaced with $200 \mu \mathrm{L}$ of media containing DMSO-dissolved curcumin (final DMSO concentration $\leq 0.1 \%$ ) or the curcumin-loaded micelles at curcumin concentrations ranging from 1 to $40 \mu \mathrm{g} / \mathrm{mL}$. Cells were incubated with treatments for 72 hours. Then the viability of the cells was determined using MTT assay. The cells were incubated with $200 \mu \mathrm{L}$ medium containing $0.5 \mathrm{mg} / \mathrm{mL}$ MTT for another 4 hours, allowing the visible cells to transform the yellow MTT into dark-blue formazan crystals, which were dissolved in $200 \mu \mathrm{L}$ of DMSO. The absorbance values were measured at $570 \mathrm{~nm}$ by an ELISA plate reader (Varioskan Flash). Hela cell viability is defined as the percent live cells compared with untreated controls. The percentage of Hela cell viability was calculated as follows:

$$
\text { Hela cell viability } \%=\frac{\mathrm{A} 570_{\text {sample }}}{\mathrm{A} 570_{\text {control }}} \times 100 \% \text {. }
$$

In this assay, all the experiments were done with ten parallel samples. Untreated cells, culture medium containing 0.1\% DMSO, and culture medium containing blank micelles were also tested as controls.

2.10. Flow Cytometric (FCM) Analysis of Cell Cycle Distribution. Flow cytometry provides information on cell cycle phases and is sensitive to apoptosis based on bivariate analysis of DNA content. For the analysis of cell cycle distribution, 
Hela cells were seeded at a density of $1.5 \times 10^{5}$ cells $/ \mathrm{mL}$ $(2 \mathrm{~mL} /$ well $)$ in 6-well plates 24 hours before the experiment. The cells were exposed to either free curcumin or the curcumin-loaded micelles at the curcumin concentration of $50 \mu \mathrm{g} / \mathrm{mL}$ in culture medium and incubated for $72 \mathrm{~h}$ in $\mathrm{CO}_{2}$ incubator at $37^{\circ} \mathrm{C}$. Cells treated with only medium were used as controls. After incubation, the cells were washed with cold PBS for three times. The cells were collected by centrifugation and fixed with $70 \%$ precooled alcohol overnight at $4{ }^{\circ} \mathrm{C}$. Before measurements, the cells were washed to eliminate alcohol and then incubated with RNase A $(0.1 \mathrm{mg} / \mathrm{mL})$ for $30 \mathrm{~min}$ at $37^{\circ} \mathrm{C}$, then stained with PI solution $(0.1 \mathrm{mg} / \mathrm{mL})$ for $30 \mathrm{~min}$ in the dark. After that the distribution of different DNA contents was analyzed by a flow cytometer (FACS Calibur, BD, USA). For each cell population, at least 10000 cells were examined.

\subsection{Annexin V-FITC/PI Double Staining. AnnexinV-FITC/} PI was used to stain the cells and the percentage of cell apoptosis was determined by flow cytometer. Hela cells were seeded at a density of $1.5 \times 10^{5}$ cells $/ \mathrm{mL}(2 \mathrm{~mL} /$ well $)$ in 6-well plates 24 hours before the experiment. The cells were exposed to either free curcumin or the curcuminloaded micelles at the curcumin concentration of $50 \mu \mathrm{g} / \mathrm{mL}$ in culture medium and incubated for $24 \mathrm{~h}$ in $\mathrm{CO}_{2}$ incubator at $37^{\circ} \mathrm{C}$. Cells treated with only medium were used as controls. At the end of the treatment period, the cells were harvested and washed twice with cold PBS. Then $1 \times 10^{5}$ cells were collected by centrifugation and gently resuspended in $200 \mu \mathrm{L}$ binding buffer; thereafter $5 \mu \mathrm{L}$ Annexin V-FITC and $10 \mu \mathrm{L}$ PI $(200 \mu \mathrm{g} / \mathrm{mL})$ were added and incubated the cells in the dark for $15 \mathrm{~min}$. Finally, $300 \mu \mathrm{L}$ binding buffer was added into the samples before they were analyzed by a flow cytometer (FACS Calibur, BD, USA).

2.12. Statistical Analyses. All the experimental data were expressed as means \pm standard deviation (SD). Statistical analyses were performed using a Student's $t$-tests. The significance of differences between groups was considered as $P<0.05$ and very significant for $P<0.01$.

\section{Result and Discussion}

3.1. Synthesis and Characterization of Copolymers. The 4arm PEG-b-PAE was synthesized via a five-step synthetic route as illustrated in Figure 1. L-lactide was polymerized in the presence of Sn (II) octoate and diethylene glycol, yielding hydroxyl-terminated poly(L-lactic acid). The hydroxylterminated poly(L-lactic acid) was converted to carboxylterminated poly(L-lactic acid) by reaction with succinic anhydride. And then the carboxyl-terminated poly(L-lactic acid) reacted with an excess of acetic anhydride, followed by melt polycondensation to obtain the PAE. The 4-arm PEG-b-PAE was prepared by esterization of the PAE and 4-arm-PEG $20 \mathrm{k}$.

The obtained polymers were characterized by ${ }^{1} \mathrm{H}-\mathrm{NMR}$ and GPC. Figure 2 shows the ${ }^{1} \mathrm{H}-\mathrm{NMR}$ spectra of the PAE and the 4-arm PEG-b-PAE. It could be found from

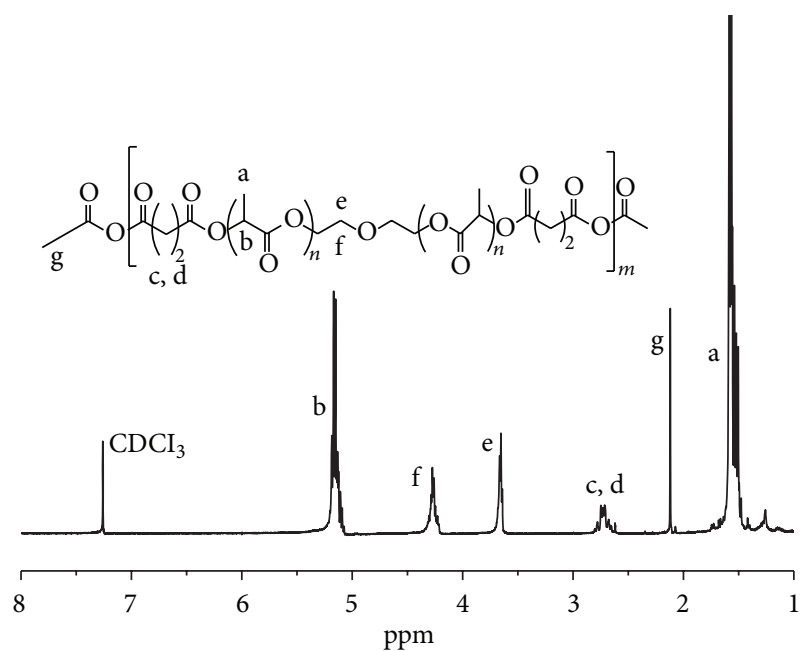

(a)

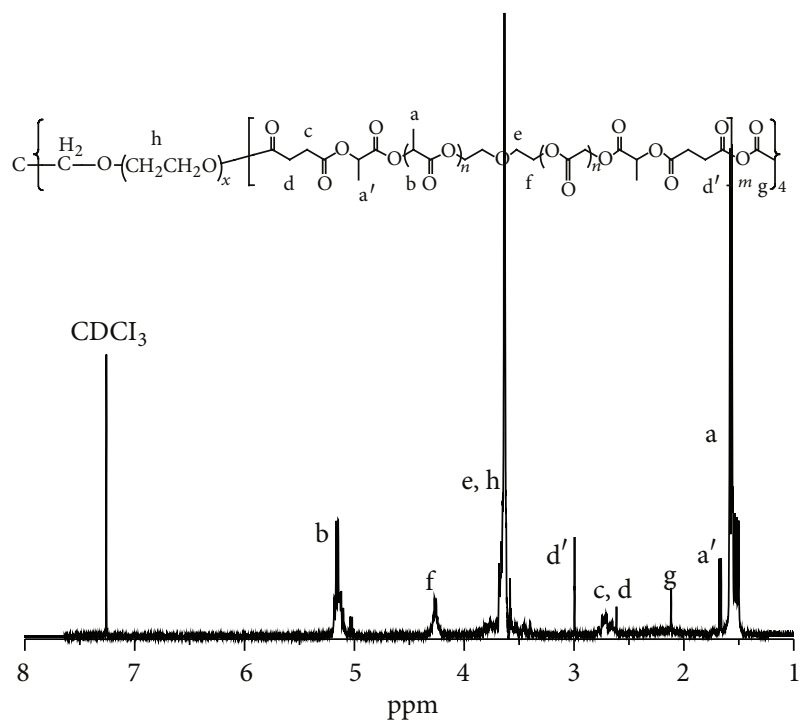

(b)

Figure 2: ${ }^{1} \mathrm{H}$-NMR spectra of (a) PAE and (b) 4-arm PEG-b-PAE.

Figure 2(a) that the peaks at $\delta 1.56-1.60,2.23,2.75-2.79,3.64-$ $3.66,4.26-4.30$, and $5.13-5.18$ ppm were attributed to the protons of $a, g, c-d, e, f$ and b of the PAE structure, respectively. In Figure 2(b), the sharp peak at 3.57-3.88 was attributed to methylene protons of the $-\mathrm{CH}_{2} \mathrm{CH}_{2} \mathrm{O}$ - in the 4-arm-PEG block of the 4-arm PEG-b-PAE. Peaks at 1.50-1.58, 1.66$1.68,2.10,2.62-2.78,2.99,4.25-4.27$, and 5.02-5.18 ppm were attributed to the corresponding protons in the PAE block of the 4-arm PEG-b-PAE, respectively. According to the peak areas of $\mathrm{Hg}, \mathrm{He}$ in Figure 2(a), the molecular weight of the PAE was calculated. The number of repeat units of anhydride was calculated according to ${ }^{1} \mathrm{H}-\mathrm{NMR}$, and the value of the PAE is about 9. Table 1 shows the chemical compositions and molecular weights of the synthesized polymers. High polydispersity of the product of coupling looks apparent from the PDI of the final polymer sample which increases from 1.58 for PAE copolymer to 2.65 for 4-arm PEG-b-PAE. It should be 
TABLE 1: Characterization of the polymers.

\begin{tabular}{lcrr}
\hline Sample & PAE content in copolymer $(w t \%)^{\mathrm{a}}$ & Mn & Theoretical $^{\text {PDI }^{\mathrm{b}}}$ \\
\hline PAE & 100 & & 5500 \\
4-arm PEG-b-PAE & 61.09 & 42000 & 39010 \\
\hline
\end{tabular}

${ }^{a}$ Calculated from the ${ }^{1} \mathrm{H}$-NMR results.

${ }^{\mathrm{b}} \mathrm{PDI}$ is the polydispersity of copolymers by GPC.

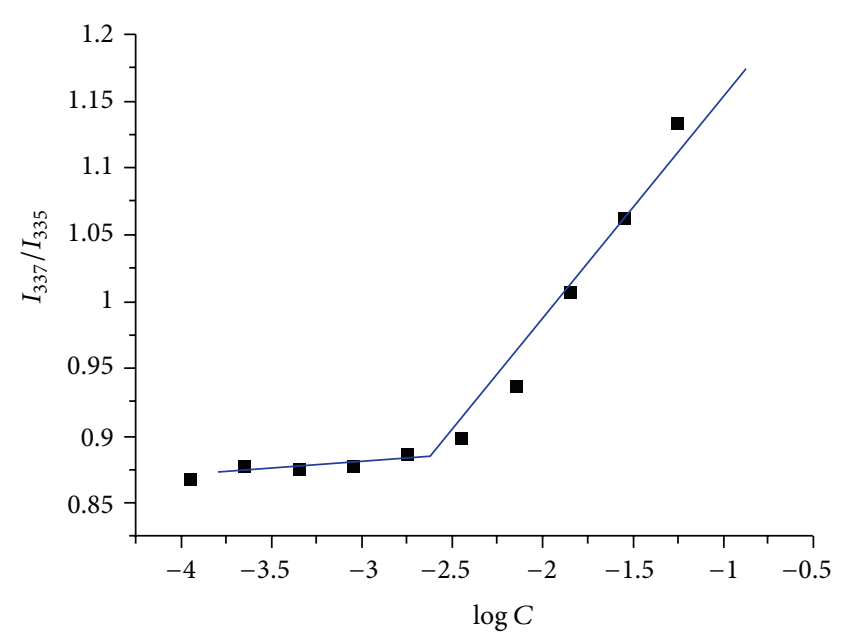

FIgURE 3: Plots of intensity ratios $I_{337} / I_{335}$ from pyrene excitation spectra versus log concentrations of the 4 -arm PEG-b-PAE.

noted that the polydispersity was determined using the linear polystyrene molecular weight standards for calibration in this study, which is not very suitable for nonlinear polymers, such as 4-arm PEG-B-PAE. Thus, it is difficult to compare the polydispersity data of PAE and 4-arm PEG-B-PAE accurately.

\subsection{Critical Micelle Concentration. Fluorescence spectro-} scopy was used to determine the CMC of the copolymer. Pyrene was used as probe to determine the association and micellization of the copolymer in solution. Pyrene had a very low solubility in water and a strong hydrophobic character, so it preferentially solubilized itself in the hydrophobic region of micelles. The process resulted in a great change of the fluorescence intensity. A shift of the peak of the excitation spectra could be observed with the changing concentration of micelles. The maximum peak for pyrene in water was about $335 \mathrm{~nm}$; the peak shifted to $337 \mathrm{~nm}$ in the solution of copolymer. So the CMC could be determined by taking a midpoint of the copolymer concentration at which point the ratio of $I_{337} / I_{335}$ was varied. As shown in Figure $3, I_{337} / I_{335}$ was low and kept constant at low copolymer concentrations and sharply increased as the copolymer concentration increased after the copolymer concentration reached a threshold that is CMC. The CMC of the 4 -arm PEG-b-PAE was $2.38 \mu \mathrm{g} / \mathrm{mL}$, which was significantly lower than that of low molecular weight surfactants in water [30] and implied the good thermodynamic stability of the 4-arm PEG-b-PAE micelles.

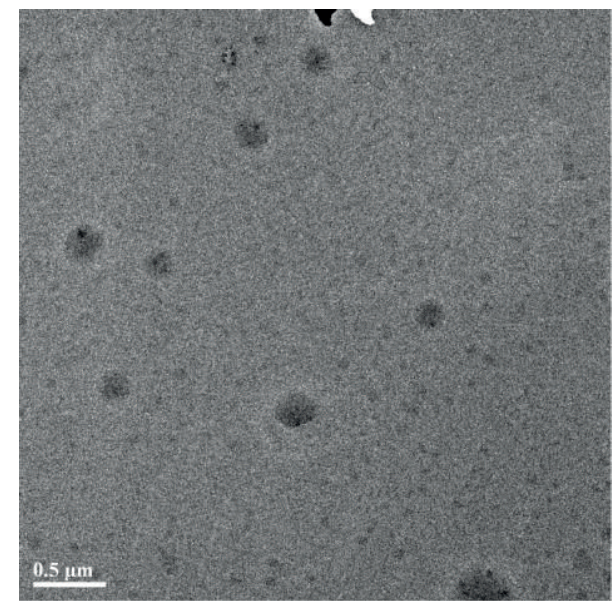

FIGURE 4: TEM image of the curcumin-loaded 4-arm PEG-b-PAE micelles.

So, it can be concluded that the 4-arm PEG-b-PAE can form stable micelles structures at its low concentration after dilution with a large volume of body fluids.

3.3. Preparation, Characterization, and Stability of Polymeric Micelles. The 4-arm PEG-b-PAE could readily produce self-assembled micelles in aqueous solution because of its amphiphilic property. The PAE part could constitute an internal hydrophobic core, while 4-arm-PEG could provide a hydrophilic outer shell of the micelles. The curcumin-loaded micelles were prepared by a solid dispersion method. The formation of micelles was confirmed by measuring particle size, size distribution, $\zeta$-potential, and morphology. The hydrodynamic diameter and zeta potential values were measured by DLS and are shown in Table 2. The hydrodynamic diameter of the particles is expressed in Z-average $(\mathrm{nm})$ and the charge as $\zeta$-potential $(\mathrm{mV})$. It shows that the hydrodynamic diameters of empty micelles and the drug loaded micelles are less than $200 \mathrm{~nm}$, with an acceptably good polydispersity index (PDI < 0.09). The zeta potential value changes a little after loading curcumin into the micelles. TEM photograph showed the curcumin-loaded micelles were spherical (Figure 4). Because of these properties, it is assumed that the curcumin-loaded micelles can effectively accumulate in the tumor region via the permeability and retention effect and exhibit reduced uptake by reticuloendothelial system [31]. 
TABLE 2: Characterization of micelles $(n=3)$.

\begin{tabular}{lccccc}
\hline Micelles & Drug loading content (\%) & Encapsulation efficiency (\%) & Size $(\mathrm{nm})$ & PDI & $\zeta$-potential (mv) \\
\hline 4-arm PEG-b-PAE & - & - & $147.1 \pm 0.1$ & $0.11 \pm 0.01$ & $-9.9 \pm 1.2$ \\
Curcumin/4-arm PEG-b-PAE & $7.0 \pm 0.2$ & $85.2 \pm 1.2$ & $151.9 \pm 0.6$ & $0.09 \pm 0.05$ & $-10.5 \pm 1.3$ \\
\hline
\end{tabular}

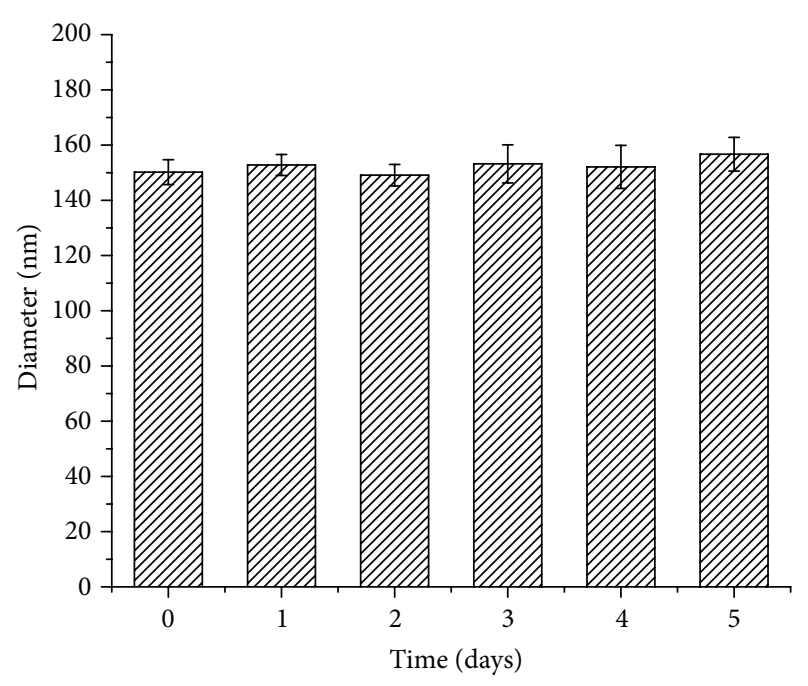

FIGURE 5: Hydrodynamic diameters of the curcumin-loaded 4-arm PEG-b-PAE micelles versus time ( $\mathrm{pH} 7.4 \mathrm{PBS}, 4^{\circ} \mathrm{C}$ ).

The physical stability of micelles in PBS ( $\mathrm{pH}$ 7.4) at $4^{\circ} \mathrm{C}$ for 5 days was assessed. No phase separation and no significant change in hydrodynamic diameter of micelles were observed (Figure 5). These results demonstrated the micelles were physically stable during the study. Owing to the high surface/volume ratio, micelles always tend to form aggregates. However, due to electrostatic interactions or/and stereospecific blockade, a stable micelles suspension can also be obtained. The zeta potential of the curcumin-loaded micelles is approximately $-10 \mathrm{mv}$, indicating that micelles presented negative surface charge. Meanwhile, 4-arm PEGb-PAE copolymer is amphiphilic and consisted of hydrophilic 4-arm PEG blocks and hydrophobic PAE blocks. In aqueous solution, the relative difference in hydrophobicity between the 4-arm PEG and the PAE blocks allows the formation of self-assembled micelles. Therefore, the stability of the curcumin-loaded micelles might be mainly contributed to the stereospecific blockade formed by the hydrophilic 4-arm PEG chain located at the surface of the curcumin-loaded micelles and the electrostatic interactions of micelles.

Drug encapsulation efficiency and drug loading content are important factors for drug delivery systems. An HPLC assay was used to determine the drug concentration in the micelles and then calculated the drug loading content and encapsulation efficiency. As it is seen from Table 2, the drug loading content of the 4-arm PEG-b-PAE micelles was

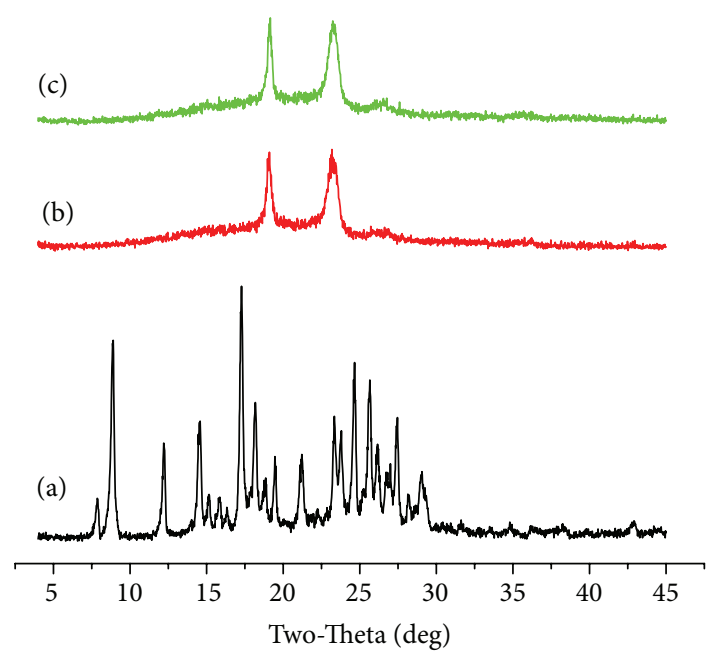

FIGURE 6: X-ray diffraction spectra of (a) curcumin, (b) empty 4arm PEG-b-PAE micelles, (c) the curcumin-loaded 4-arm PEG-bPAE micelles.

$7.0 \pm 0.2 \%$ and the encapsulation efficiency of the micelle was $85.2 \pm 1.2 \%$, which achieve high drug encapsulation efficiency.

To examine the crystallinity of micelle-encapsulated curcumin, XRD analysis was performed on the curcuminloaded micelles. Figure 6 presents the XRD spectra of the curcumin powders, empty 4-arm PEG-b-PAE micelles, and the curcumin-loaded 4-arm PEG-b-PAE micelles. It could be found that the characteristic diffraction peaks of the curcumin were absent in the spectrum of the curcuminloaded micelles, which might suggest the curcumin was encapsulated within the micelles amorphously.

3.4. In Vitro Curcumin Release. Figure 7 shows the cumulative release profiles of curcumin from the curcumin-loaded micelles under different $\mathrm{pH}$ conditions ( $\mathrm{pH} 5.0$ and 7.4) at $37^{\circ} \mathrm{C}$. Curcumin release from the micelles was monitored for 9 days. Sustained drug release was observed and it was dependent on the $\mathrm{pH}$ of the release medium. The cumulative release of curcumin from the curcumin-loaded micelles could reach up to $99.5 \%$ after 9 days at $\mathrm{pH} 5.0$, higher than that at $\mathrm{pH}$ 7.4, which was 70\%. Curcumin released from the micelles consisted of two phases. An initial fast release for about $12 \mathrm{~h}$ was followed by a sustained released of drug from the micelles. In Phase 1, the drug adsorbed on the surface of the micelles was separated from the carrier material into the aqueous phase, which contributed to the burst release stage. 


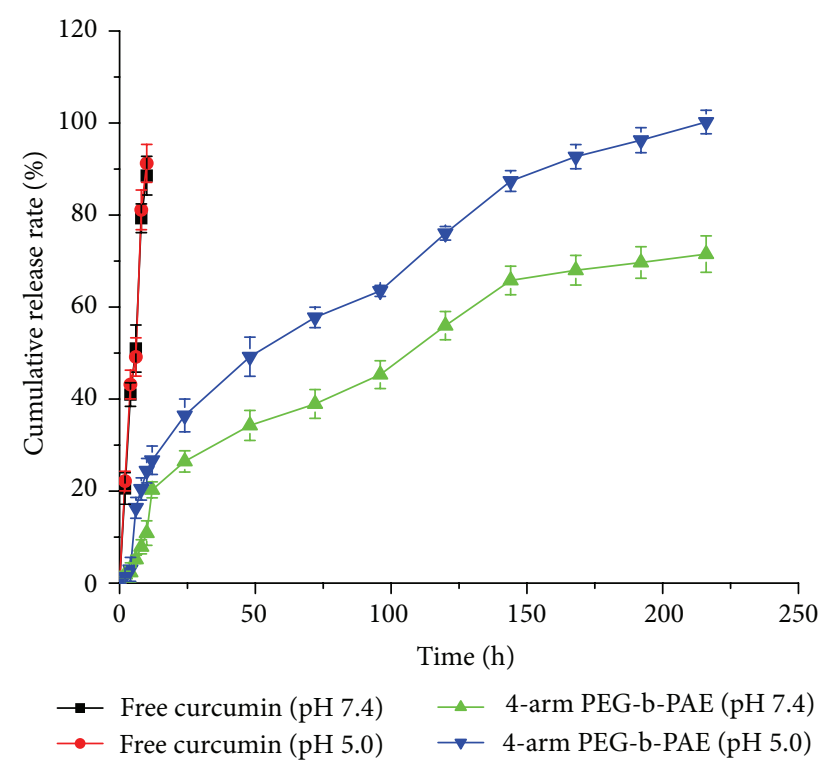

FIGURE 7: Drug release profiles of the curcumin-loaded 4-arm PEGb-PAE micelles.

3.5. Hemolysis of Micelles. The hemolysis rate of the curcumin-loaded 4-arm PEG-b-PAE micelles was $3.18 \pm 1.27 \%$, which was below 5\%, indicating that the micelles will not lead to severe hemolysis, according to ISO 10993-4:2002. Therefore, it is suggested that the curcumin-loaded micelles have no destructive effect on erythrocyte.

3.6. Cellular Uptake of the Curcumin-Loaded Micelles. Cellular uptake of the curcumin-loaded micelles in Hela cell was investigated by flow cytometer. To investigate the effect of time on the micelles uptake by Hela cells, cells were incubated with the micelles for various periods and the mean fluorescence intensity of cells was analyzed. The results were shown in Figure 8. The cells untreated with the micelles were used as negative control to direct autofluorescence. It can be found that the histograms of 0.5 and 2 hours move to right and the histograms of 4 and 24 hours move much more to right, especially the histogram of 24 hours, comparing with the histogram of blank. The mean fluorescence intensity of cells after incubation of 0.5, 2, 4, 24 hours was 5649, 6497, 17395 , and 24644 , respectively. These results demonstrate that the cellular uptake of the curcumin-loaded micelles in Hela cell increased in a time-dependent manner.

3.7. In Vitro Cytotoxicity. As shown in Figure 9, the cytotoxicity of both the curcumin-loaded micelles and free curcumin to Hela cells at 72 hours showed significant concentration dependence. Half-maximal inhibitory concentrations $\left(\mathrm{IC}_{50}\right)$ of the curcumin-loaded micelles and free curcumin to Hela cells were $10.21 \mu \mathrm{g} / \mathrm{mL}$ and $25.90 \mu \mathrm{g} / \mathrm{mL}$, respectively. From these results, it can be observed that the curcuminloaded micelles have better efficiency than free curcumin. In addition, the toxicity of the 4-arm PEG-b-PAE used to delivery curcumin was tested. No cytotoxicities at the test

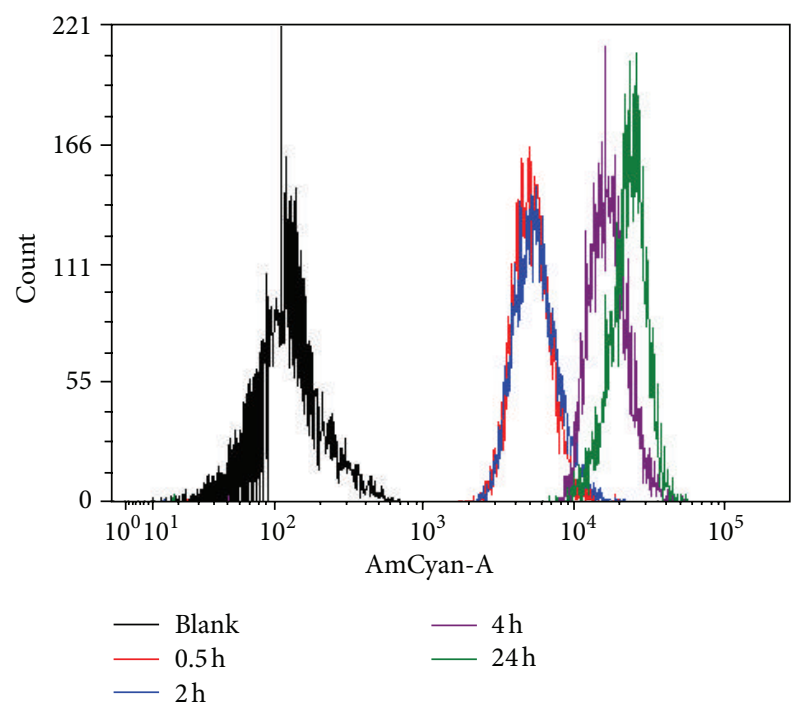

(a)

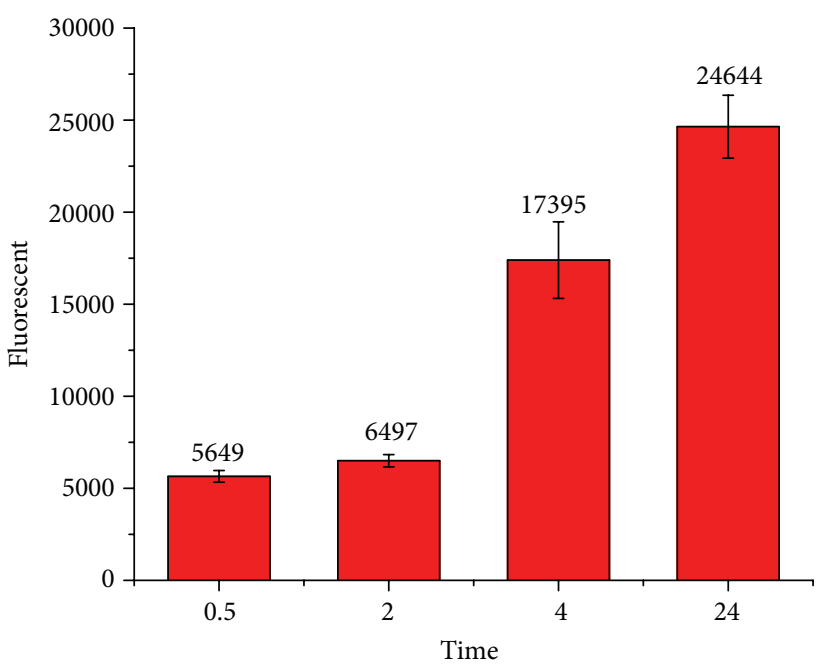

(b)

FIGURE 8: Cellular uptake of the curcumin-loaded 4-arm PEG-bPAE micelles by Hela cells at $37^{\circ} \mathrm{C}$ using flow cytometer. (a) Flow histograms of cellular uptake. (b) Mean fluorescence intensity of Hela cells incubated with the curcumin-loaded 4-arm PEG-b-PAE micelles.

range concentrations of the 4-arm PEG-b-PAE were observed at $72 \mathrm{~h}$ (data not shown).

3.8. The Curcumin-Loaded Micelles Induced Cell Cycle Arrest in Hela Cells. Figure 10 shows the cell cycle histograms of Hela cells treated with blank control, free curcumin, and the curcumin-loaded micelles for $72 \mathrm{~h}$. After the cells were treated with free curcumin or the curcumin-loaded micelles, the percent of cells in $\mathrm{G}_{2} / \mathrm{M}$ phase increased to $19.18 \pm$ $0.43 \%$ and $28.10 \pm 0.21 \%$, respectively, which differed from blank control $(9.24 \pm 1.78 \%)$. These data suggested that the curcumin-loaded micelles showed more significant cell cycle arrest effect at $\mathrm{G}_{2} / \mathrm{M}$ phase in Hela cells compared 


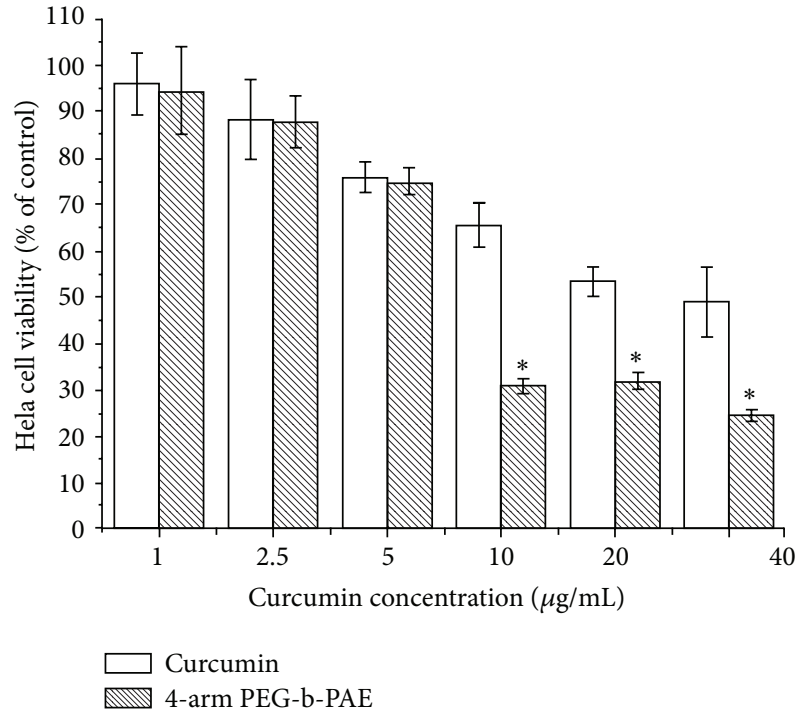

Figure 9: Cytotoxicity of the curcumin-loaded 4-arm PEG-b-PAE micelles against Hela cells. Incubation time was $72 \mathrm{~h}$, data were presented as mean \pm SD $(n=10)$. * Significant difference between the curcumin-loaded 4-arm PEG-b-PAE micelles and free curcumin $(P<0.05)$

to free curcumin at the same concentration. The result appears to be consistent with that of the in vitro cytotoxicity experiments.

3.9. Cell Apoptotic Rate Detected by FCM. Annexin V/PI double staining is a sensitive method in detecting apoptosis. Externalization of phosphatidyl serine (PS) from the inner side to outer leaflet of the cell membrane is an important indication of early apoptosis. Annexin V possesses a high affinity towards PS; early apoptotic cells can be easily detected by fluorescently labeled Annexin V. Meanwhile, PI can detect necrotic cells due to its permeability through the damaged cell membranes [32]. As shown in Figure 11, after $72 \mathrm{~h}$ treatment, the percentages of early and late apoptosis of the curcuminloaded micelles-treated cells were $43.01 \pm 2.60 \%$ and $56.35 \pm$ $0.41 \%$, respectively, while those of curcumin-treated cells were $5.28 \pm 0.32 \%$ and $87.19 \pm 1.88 \%$, respectively. The total apoptosis rates of Hela cells caused by curcumin and the curcumin-loaded micelles were $92.47 \pm 2.20 \%$ and $99.36 \pm 0.56 \%$, respectively. Obviously, in comparison with free curcumin, the curcumin-loaded micelles could promote a higher apoptotic rate in Hela cells at the same dose. The result agreed with that of our in vitro cytotoxicity experiments.

\section{Conclusions}

Amphiphilic block copolymer 4-arm poly(ethylene glycol)b-Poly(anhydride-esters) (4-arm PEG-b-PAE) was successfully synthesized. The 4-arm PEG-b-PAE is able to selfassemble in water to form micelles as curcumin nanocarrier.

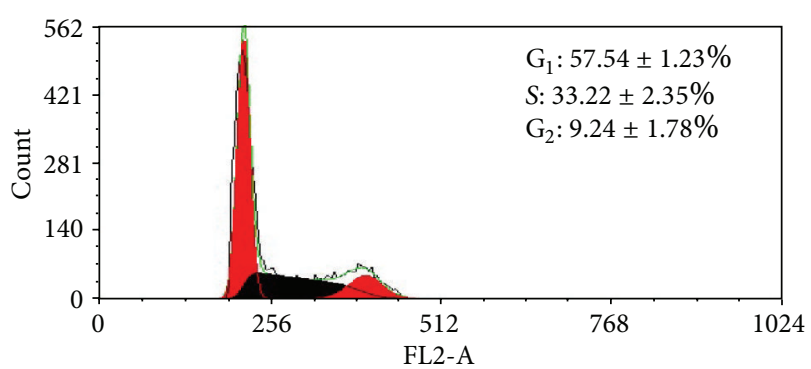

(a)

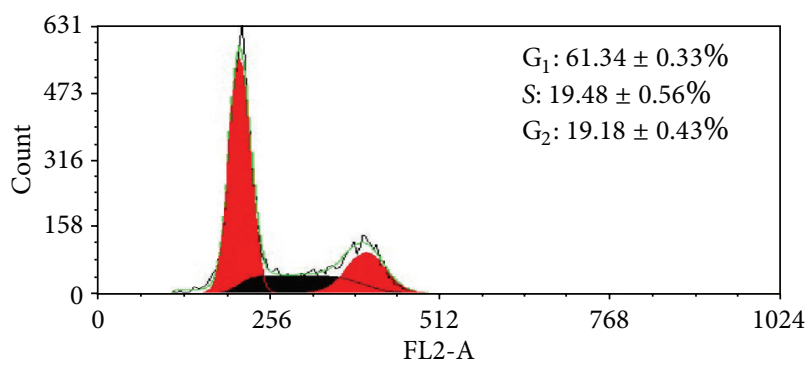

(b)

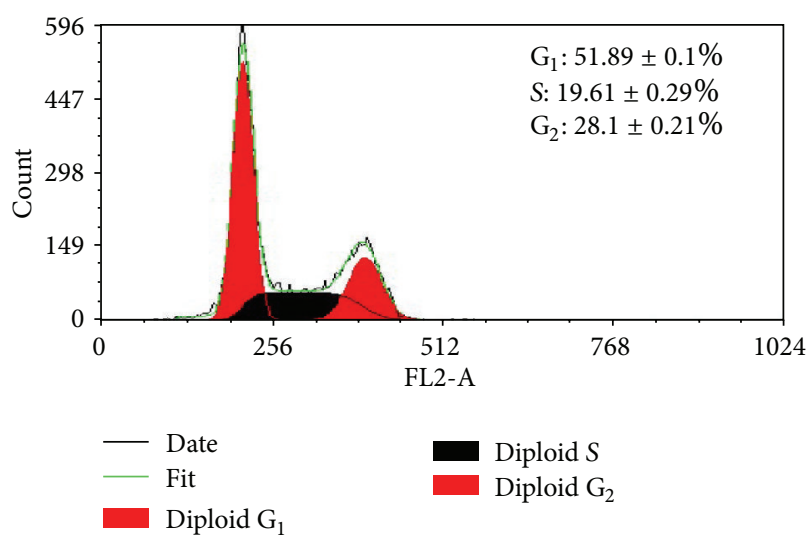

(c)

Figure 10: Flow cytometer analysis of cell cycle distribution. Hela cells were treated with free curcumin and the curcumin loaded micelles at the curcumin concentration of $50 \mu \mathrm{g} / \mathrm{mL}$ for $24 \mathrm{~h}$. (a) Control, (b) free curcumin, and (c) the curcumin-loaded 4-arm PEG-b-PAE micelles.

The critical micelles concentration of the 4-arm PEG-b-PAE was $2.38 \mu \mathrm{g} / \mathrm{mL}$, which implied the good thermodynamic stability of 4-arm PEG-b-PAE micelles. Curcumin was released from the 4-arm PEG-b-PAE micelles, faster in $\mathrm{pH} 5.0$ than $\mathrm{pH}$ 7.4, presenting one biphasic drug release pattern with rapid release at the initial stage and slow release later. The cellular uptake of the the curcumin-loaded micelles in Hela cell increased in a time-dependent manner. The curcumin loaded PAE-b-PEG micelles had higher toxicity to Hela cells than free curcumin, which could induce $G_{2} / M$ phase arrest and apoptosis of Hela cells. 


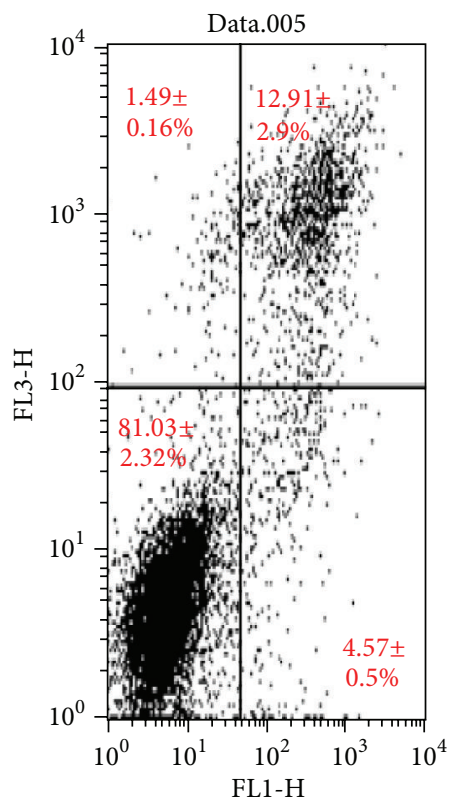

(a)

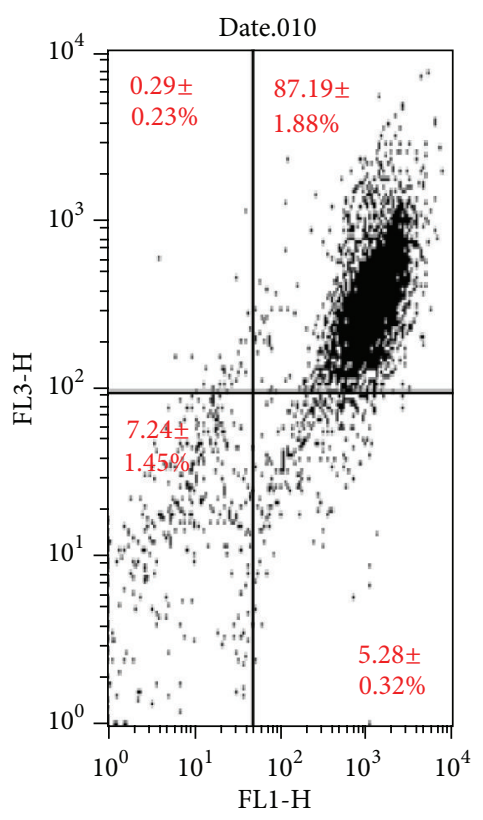

(b)

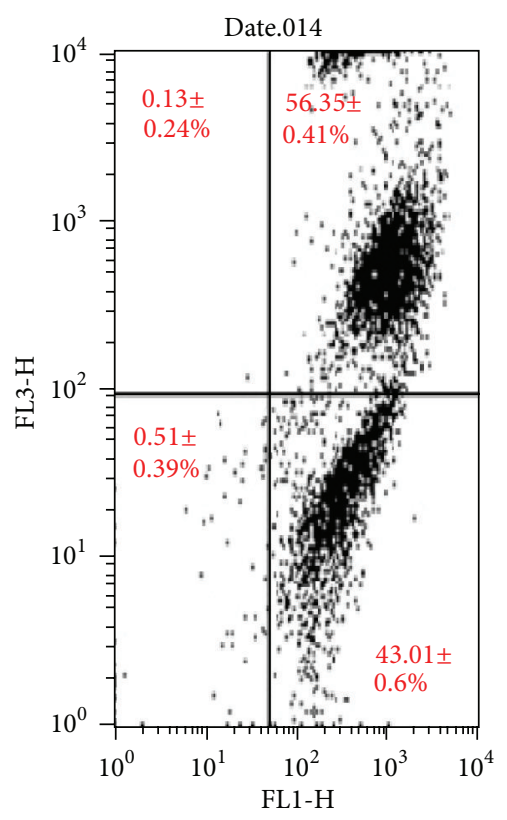

(c)

FIGURE 11: Cell apoptotic rate detected by flow cytometer. Hela cells were treated with curcumin and the curcumin-loaded micelles at the curcumin concentration of $50 \mu \mathrm{g} / \mathrm{mL}$ for $72 \mathrm{~h}$. (a) Blank control, (b) Free curcumin, and (c) the curcumin-loaded 4-arm PEG-b-PAE micelles.

\section{Authors' Contribution}

Li Lv, Yuanyuan Shen, and Min Li are equal contributors.

\section{Conflict of Interests}

The authors declare that there is no conflict of interests with the trademarks mentioned in the paper. They have no financial and personal relationships with other people or organizations that can inappropriately influence their work.

\section{Acknowledgments}

This work is supported by National Natural Science Foundation of China (NSFC) (Grant no. 81171439), National Basic Research Program of China (973 Program, Grant 2010CB529902), and the National Key Technology R\&D Program of the Ministry of Science and Technology (2012BAI18B01). The authors are grateful to Instrumental Analysis Center of Shanghai Jiao Tong University and Professor Che for their technical support in XRD and TEM examinations.

\section{References}

[1] N. Kumar, R. S. Langer, and A. J. Domb, "Polyanhydrides: an overview," Advanced Drug Delivery Reviews, vol. 54, no. 7, pp. 889-910, 2002.

[2] U. Edlund and A. C. Albertsson, "Polyesters based on diacid monomers," Advanced Drug Delivery Reviews, vol. 55, no. 4, pp. 585-609, 2003.
[3] J. P. Jain, S. Modi, A. J. Domb, and N. Kumar, "Role of polyanhydrides as localized drug carriers," Journal of Controlled Release, vol. 103, no. 3, pp. 541-563, 2005.

[4] L. S. Nair and C. T. Laurencin, "Biodegradable polymers as biomaterials," Progress in Polymer Science, vol. 32, no. 8-9, pp. 762798, 2007.

[5] V. Zabaleta, G. Ponchel, H. Salman, M. Agüeros, C. Vauthier, and J. M. Irache, "Oral administration of paclitaxel with pegylated poly(anhydride) nanoparticles: permeability and pharmacokinetic study," European Journal of Pharmaceutics and Biopharmaceutics, vol. 81, no. 3, pp. 514-523, 2012.

[6] L. Huntimer, J. H. W. Welder, K. Ross et al., "Single immunization with a suboptimal antigen dose encapsulated into polyanhydride microparticles promotes high titer and avid antibody responses," Journal of Biomedical Materials Research $B$, vol. 101, no. 1, pp. 91-98, 2013.

[7] Y. Liang, L. Xiao, Y. Zhai, C. Xie, L. Deng, and A. Dong, "Preparation and characterization of biodegradable poly(sebacic anhydride) chain extended by glycol as drug carrier," Journal of Applied Polymer Science, vol. 127, no. 5, pp. 3948-3953, 2013.

[8] A. Göpferich and J. Tessmar, "Polyanhydride degradation and erosion," Advanced Drug Delivery Reviews, vol. 54, no. 7, pp. 911931, 2002.

[9] M. Martina and D. W. Hutmacher, "Biodegradable polymers applied in tissue engineering research: a review," Polymer International, vol. 56, no. 2, pp. 145-157, 2007.

[10] W. Dang, T. Daviau, P. Ying et al., "Effects of GLIADEL wafer initial molecular weight on the erosion of wafer and release of BCNU," Journal of Controlled Release, vol. 42, no. 1, pp. 83-92, 1996.

[11] G. Gaucher, M. H. Dufresne, V. P. Sant, N. Kang, D. Maysinger, and J. Leroux, "Block copolymer micelles: preparation, characterization and application in drug delivery," Journal of Controlled Release, vol. 109, no. 1-3, pp. 169-188, 2005. 
[12] R. F. Storey and A. E. Taylor, "Synthesis of novel biodegradable poly(ester-anhydride)s," Journal of Macromolecular Science A, vol. 34, no. 2, pp. 265-280, 1997.

[13] B. A. Pfeifer, J. A. Burdick, and R. Langer, "Formulation and surface modification of poly(ester-anhydride) micro- and nanospheres," Biomaterials, vol. 26, no. 2, pp. 117-124, 2005.

[14] R. A. Hakala, H. Korhonen, V. V. Meretoja, and J. V. Seppälä, "Photo-cross-linked biodegradable poly(ester anhydride) networks prepared from alkenylsuccinic anhydride functionalized poly(E-caprolactone) precursors," Biomacromolecules, vol. 12, no. 7, pp. 2806-2814, 2011.

[15] M. L. Adams, A. Lavasanifar, and G. S. Kwon, "Amphiphilic block copolymers for drug delivery," Journal of Pharmaceutical Sciences, vol. 92, no. 7, pp. 1343-1355, 2003.

[16] N. Zhang, S. R. Guo, H. Q. Li, L. Liu, Z. H. Li, and J. R. Gu, "Synthesis of three types of amphiphilic poly(ethylene glycol)block-poly(sebacic anhydride) copolymers and studies of their micellar solutions," Macromolecular Chemistry and Physics, vol. 207, no. 15, pp. 1359-1367, 2006.

[17] S. Hou, L. K. McCauley, and P. X. Ma, "Synthesis and erosion properties of PEG-containing polyanhydrides," Macromolecular Bioscience, vol. 7, no. 5, pp. 620-628, 2007.

[18] F. Najafi and M. N. Sarbolouki, "Biodegradable micelles/ polymersomes from fumaric/sebacic acids and poly(ethylene glycol)," Biomaterials, vol. 24, no. 7, pp. 1175-1182, 2003.

[19] R. K. Maheshwari, A. K. Singh, J. Gaddipati, and R. C. Srimal, "Multiple biological activities of curcumin: a short review," Life Sciences, vol. 78, no. 18, pp. 2081-2087, 2006.

[20] S. M. Oliveira, I. F. Amaral, M. A. Barbosa, and C. C. Teixeira, "Engineering endochondral bone: in vitro studies," Tissue Engineering $A$, vol. 15, no. 3, pp. 625-634, 2009.

[21] L. Song, Y. Shen, J. Hou, L. Lei, S. Guo, and C. Qian, "Polymeric micelles for parenteral delivery of curcumin: preparation, characterization and in vitro evaluation," Colloids and Surfaces A, vol. 390, no. 1-3, pp. 25-32, 2011.

[22] S. Singh and B. B. Aggarwal, "Activation of transcription factor NF- $\kappa$ b is suppressed by curcumin (diferuloylmethane)," The Journal of Biological Chemistry, vol. 270, no. 42, pp. 2499525000, 1995.

[23] A. B. Kunnumakkara, P. Anand, and B. B. Aggarwal, "Curcumin inhibits proliferation, invasion, angiogenesis and metastasis of different cancers through interaction with multiple cell signaling proteins," Cancer Letters, vol. 269, no. 2, pp. 199-225, 2008.

[24] E. O. Farombi, S. Shrotriya, and Y. J. Surh, "Kolaviron inhibits dimethyl nitrosamine-induced liver injury by suppressing COX-2 and iNOS expression via NF- $\kappa$ B and AP-1," Life Sciences, vol. 84, no. 5-6, pp. 149-155, 2009.

[25] K. Mehta, P. Pantazis, T. McQueen, and B. B. Aggarwal, "Antiproliferative effect of curcumin (diferuloylmethane) against human breast tumor cell lines," Anti-Cancer Drugs, vol. 8, no. 5, pp. 470-481, 1997.

[26] A. L. Chen, C. H. Hsu, J. K. Lin et al., "Phase I clinical trial of curcumin, a chemopreventive agent, in patients with high-risk or pre-malignant lesions," Anticancer Research, vol. 21, no. 4, pp. 2895-2900, 2001.

[27] C. D. Lao, M. T. Ruffin IV, D. Normolle et al., "Dose escalation of a curcuminoid formulation," BMC Complementary and Alternative Medicine, vol. 6, article 10, 2006.

[28] C. L. Zhao, M. A. Winnik, G. Riess, and M. D. Croucher, "Fluorescence probe techniques used to study micelle formation in water-soluble block copolymers," Langmuir, vol. 6, no. 2, pp. 514-516, 1990.

[29] Y. Wang, C. Wang, C. Gong et al., "Polysorbate 80 coated poly ( $\varepsilon$-caprolactone)-poly (ethylene glycol)-poly ( $\varepsilon$-caprolactone) micelles for paclitaxel delivery," International Journal of Pharmaceutics, vol. 434, no. 1-2, pp. 1-8, 2012.

[30] K. Y. Lee, I. C. Kwon, Y. H. Kim, W. H. Jo, and S. Y. Jeong, "Preparation of chitosan self-aggregates as a gene delivery system," Journal of Controlled Release, vol. 51, no. 2-3, pp. 213220, 1998.

[31] H. Xin, X. Jiang, J. Gu et al., "Angiopep-conjugated poly(ethylene glycol)-co-poly( $\varepsilon$-caprolactone) nanoparticles as dualtargeting drug delivery system for brain glioma," Biomaterials, vol. 32, no. 18, pp. 4293-4305, 2011.

[32] H. Lou, L. Gao, X. Wei et al., "Oridonin nanosuspension enhances anti-tumor efficacy in SMMC-7721 cells and $\mathrm{H} 22$ tumor bearing mice," Colloids and Surfaces B, vol. 87, no. 2, pp. 319-325, 2011. 

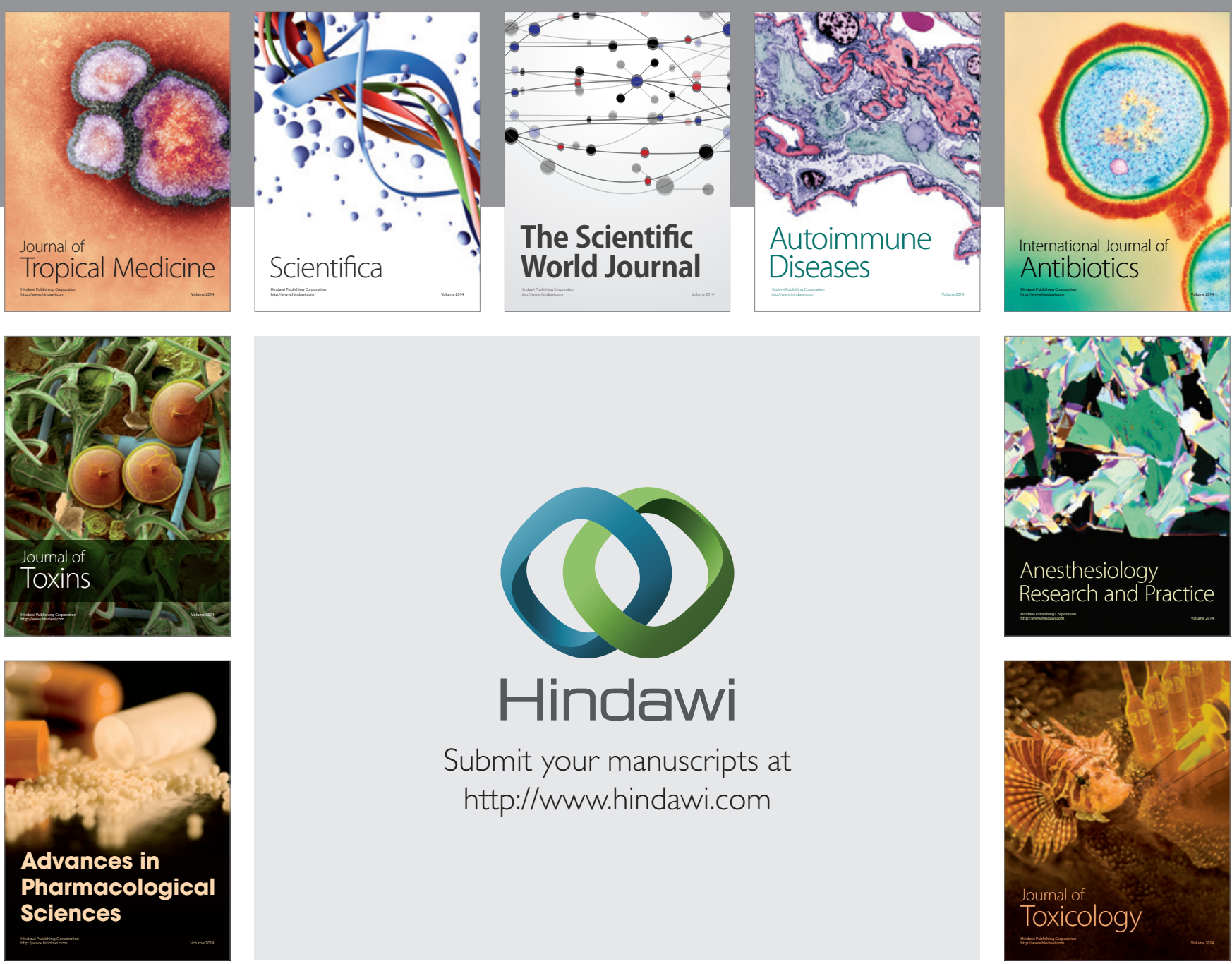

\section{Hindawi}

Submit your manuscripts at

http://www.hindawi.com
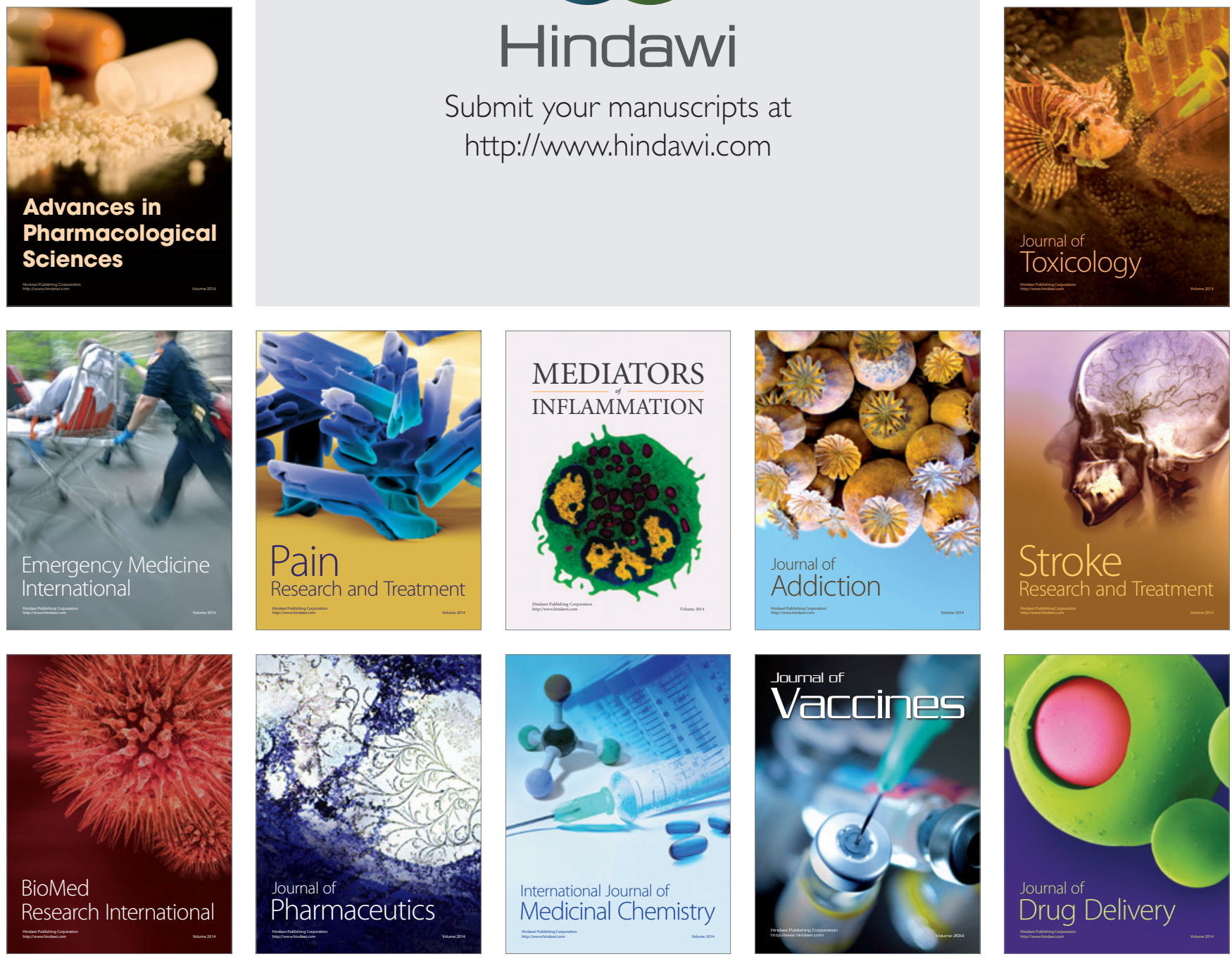